\title{
常圧のアンモニアガス中におけるイミドニ硫酸アンモニウムのアアンモノリシスと平衡
}

\section{および $\mathrm{NH}_{4} \mathrm{SO}_{3} \mathrm{NH}_{2}$ - $\left(\mathrm{NH}_{4} \mathrm{SO}_{3}\right)_{2} \mathrm{NH}$ 間混合物の融点図}

(昭 和 44 年 2 月 8 日 受 理)

伊藤 幸 夫*1

常压のアンモニアガス中でイミド二硫酸アンモニウムを $250 \sim 300^{\circ} \mathrm{C}$ に加熱すると，その $30 〜 50 \%$ がスルファミン酸フンモニ ウムに変化する。

この反応は,スルファミン酸アンモニゥムの熱分解反応の逆反応であり，両者の間には次の平衡がある。 $\left(\mathrm{NH}_{4} \mathrm{SO}_{3}\right)_{2} \mathrm{NH}+\mathrm{NH}_{3} \rightleftharpoons 2 \mathrm{NH}_{4} \mathrm{SO}_{3} \mathrm{NH}_{2}$

160 310 ${ }^{\circ} \mathrm{C}$ 間に扣けるその平衡組成を測定した結果，スルファミン酸フンモニウムの含量はつきのとおりであった。 $160^{\circ} \mathrm{C}: 96.0 \%, 180^{\circ} \mathrm{C}: 78.4 \%, 200^{\circ} \mathrm{C}: 66.8 \%, 250^{\circ} \mathrm{C}: 54.0 \%, 280^{\circ} \mathrm{C}: 40.4 \%, 310^{\circ} \mathrm{C}: 33.7 \%$

また，空気中あるいはフンモニアガス中における $\mathrm{NH}_{4} \mathrm{SO}_{3} \mathrm{NH}_{2}-\left(\mathrm{NH}_{4} \mathrm{SO}_{3}\right)_{2} \mathrm{NH}$ 間混合物の凝固点または融点を測定して融点図を つくった。その結果, スルファミン酸アンモニウム挍よびイミド二硫酸アンモニウムの融点は, それぞれ $132.8^{\circ} \mathrm{C}$ おひび $325^{\circ} \mathrm{C}$

で，共融点は $124.2^{\circ} \mathrm{C}$, イミド二硫酸フンモニウム $12 \%$ であり，両者の間には化合物も固溶体も生じないことがわかった。

これらの結果に基ついて，既報のスルファミン酸フンモニウム加圧合成の工業的実施に拈いて，原料の反応器への供給法として 考案したイミド二硫酸アンモニウムをスルファミン酸アンモニウムの溶融液中に眊濁または溶解させて加压反応器へ供給する方法 を検討した。

\section{1 楮言}

スルファミン酸アンモニウムを空気中で加熱すると, $160^{\circ} \mathrm{C}$ 付 近からアンモニアを放出してイミド二硫酸アンモニウひに変化す $2 \mathrm{NH}_{4} \mathrm{SO}_{3} \mathrm{NH}_{2} \longrightarrow\left(\mathrm{NH}_{4} \mathrm{SO}_{3}\right)_{2} \mathrm{NH}+\mathrm{NH}_{3}$ るスルファミン酸アンモニウムの熱分解が始まり，この反応は

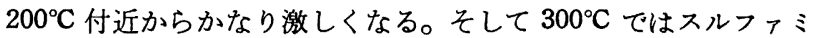
ン酸アンモニウムの大部分がイミド二硫酸アンモニウムに分解す る。これはイミド二硫酸アンモニウムの実験室的製法として用い られている1)ものである。

著者はさきにイミド二硫酸アンモニウムをアンモニア加圧下で $230^{\circ} \mathrm{C}$ 付近に加熱すると, この逆反応

$$
\left(\mathrm{NH}_{4} \mathrm{SO}_{3}\right)_{2} \mathrm{NH}+\mathrm{NH}_{3} \longrightarrow 2 \mathrm{NH}_{4} \mathrm{SO}_{3} \mathrm{NH}_{2}
$$

が起こってスルフォミン酸アンモニウムに変化することを見いだ したが2)，この反応は常圧のアンモニアガス中でも起こり，また， (1)，(2) 間の反応には平衡があることを新たに見いだした。

ところですでに報告したように，上記のアンモニア加圧法は， アンモニアの圧 $30 \mathrm{~atm}$, 温度 $230^{\circ} \mathrm{C}$ の条件では，(2）の反応に よって容易に約 $90 \%$ のスルファミン酸アンモニウムを含む生成 物が得られるので，スルファミン酸アンモニウムの有利な工業的 製法として期待ができるが，この方法の工業的実施にあたって は, 固体のイミド二硫酸アンモニウムを高温, 加圧下の反応器へ どのようにして供給していくかといらことが問題点となってい た。

著者はこれについてスルファミン酸アンモニウムの溶融液中に イミド二硫酸アンモニウム $\left(\mathrm{NH}_{3}-\mathrm{SO}_{3}\right.$ 間反応生成物) を懸濁また は溶解させて加圧反応器へ供給することを考え，これを基礎的に 検討するため，常仕のアンモニアガス中に拈けるイミド二硫酸ア

*1 Yukio ITO 工業技術院東京工業試験所：東京都沿谷区本 町.

1) W. Fernelius, "Inorganic Syntheses Vol. II", McGrawHill Book Company, Inc., New Yok (1946) p. 180.

2）伊藤幸夫，工化，57，797，800 (1954).
ンモニウムのアンモノリシス, $160 \sim 310^{\circ} \mathrm{C}$ 間における（1)，(2) の反応における平衡組成および $\mathrm{NH}_{4} \mathrm{SO}_{3} \mathrm{NH}_{2}-\left(\mathrm{NH}_{4} \mathrm{SO}_{3}\right)_{2} \mathrm{NH}$ 間混 合物の融点などについて研究した。

\section{2 実 験 方 法}

\section{$2 \cdot 1$ 試 料}

イミド二硫酸アンモニウムは，アンモニアと三酸化イオウとの 反応で作った粗製品を微アンモニア性の水で 2 回再結晶して作っ た。純度 $99.9 \%$ また，スルフォミン酸アンモニウムは, 純ス ルファミン酸をアンモニアで中和) して作った。

\section{$2 \cdot 2$ 実銩方法}

$2 \cdot 2 \cdot 1$ 常圧のアンモニアカス中におけるイミトニ硫酸アンモ ニウムのアンモノリシス 約 $5 \mathrm{~g}$ のイミド二硫酸アンモニウムを ガスの導入, 排気管の付いた内容 $300 \mathrm{ml}$ のガラスセン付三角フ ラスコにとり，これをマントルヒーターまたはりルトバス中に入 れ，フラスコ中の空気をアンモニアガスで置換し，加熱して所定 の温度とし，所定の時間その温度に保った後，ただちに冷却して 生成物を分析した。

分析は既報の方法に準じ， $\mathrm{a}: \mathrm{NH}_{3}$ を酸アルカリ滴定法， b : $\mathrm{NH}$ を加水分解法, $\mathrm{c}: \mathrm{NH}+\mathrm{NH}_{2}$ を亜硝酸塩滴定法で測定し, 各 成分のモル数を次のようにして求め,

$\mathrm{NH}_{3}: \mathrm{a}, \quad\left(\mathrm{NH}_{4} \mathrm{SO}_{3}\right)_{2} \mathrm{NH}: \mathrm{b}, \quad \mathrm{NH}_{4} \mathrm{SO}_{3} \mathrm{NH}_{2}: \mathrm{c}-\mathrm{b}$

これらを重量に換算して試料中の重量 \%を出した。またこれら の合計を $100 \%$ から差し引いたものを硫酸アンモニウムとした*2。

$2 \cdot 2 \cdot 2$ 常殴のアンモニアカスイにおける $2 \mathbf{N H}_{4} \mathbf{S O}_{3} \mathbf{N H}_{2} \rightleftharpoons$ $\left(\mathbf{N H}_{4} \mathbf{S O}_{3}\right)_{2} \mathbf{N H}+\mathbf{N H}_{3}$ の平衡組成の測定 イミド二硫酸アンモ ニウム側からの反応は $250^{\circ} \mathrm{C}$ 以下ではほとんど進行しないので, 平衡組成の測定はスルファミン酸アンモニウム側からの反応によ った。

デシケーター中で十分乾燥した純スルフォミン酸アンモニウム

3）伊藤幸夫，工化，63，1685（1960）

*2これには微量の組成不明のイオウー窒素化合物が含まれる 可能性がある。 
$5 \mathrm{~g}$ を2・2・1 で述べた三角フラスコ中にとり, 恒温浴 $\left( \pm 0.5^{\circ} \mathrm{C}\right)$ 中に入れ，フラスコ内の空気をアンモニアガスで置換した後，加 熱して所定の温度とし，平衡に達するまでその温度に保った。浴 は $250^{\circ} \mathrm{C}$ まはシリコーン油を用い, それ以上の温度の場合はり ルトバスを用いた。平衡点への到達は, スルファミン酸アンモニ ウムの熱分解によって発生するアンモニアガスの気泡が，溶融夜 から出なくなることによって判定した。（実際にはその点よりさ らに長時間その温度に保った)。生成物はただちに冷却して取り 出し，2・2・1 に述べた分析方法によって分析した。なお，生成物 中の $\mathrm{NH}_{3}$ は, 反応後冷却の際イミド二硫酸アンモニウムに吸収 されたものであるので, 結果の計算にはこれを除いて各成分の\% を求めた。

\section{$2 \cdot 2 \cdot 3 \quad \mathrm{NH}_{4} \mathrm{SO}_{3} \mathrm{NH}_{2}-\left(\mathrm{NH}_{4} \mathrm{SO}_{3}\right)_{2} \mathrm{NH}$ 间混合物の凝固点または} 融点の測定 装置および測定方法は Thelin らの方法) に準じた。 しかしこの場合は，外管が融着された測定管を用いると都合が悪 いので，測定管と外管とを別々にし，測定管を数多く作って，ス ルファミン酸アンモニウムとイミド二硫酸アンモニウムとをいろ いろの比に混ぜたものをそれらに入れ，これを濃硫酸入りデシヶ 一ター中で減圧下で二週間放置して十分乾燥し, 測定の際にはこ れらに外管をつけて測定した。これはスルファミン酸アンモニウ ムが吸湿性があるため，両者を空気中ではかって混ぜ，測定管に 入れて測定すると，ぞうしても試料中に水分が入り，加熱の際イ ミド二硫酸アンモニウムが加水分解して測定值が低く出ることが わかったからである。

なお，測定管には温度計および先に白金線を付けたかきまぜ用 ガラス棒のそら入孔のあるセンをし，また，アンモニアガス中で 測定する場合は，さらにアンモニアガスの導入管および排気管の 付いたセンをした。また，加熱浴は $250^{\circ} \mathrm{C}$ まではシリコーン油， それ以上の温度ではソルトバスを用いた。

一方, $\mathrm{NH}_{4} \mathrm{SO}_{3} \mathrm{NH}_{2}-\left(\mathrm{NH}_{4} \mathrm{SO}_{3}\right)_{2} \mathrm{NH}$ 間の存在物質については凝 固点または融点測定後の試料をX 線回折によって調べた。

\section{3 結 果と考察}

3.1 イミドニ硫酸アンモニウムよりスルファミン酸アンモニ ウムへの変化

実験結果を表 1 に示す。これよりアンモニアガス中でイミド二 硫酸アンモニウムを $250 \sim 290^{\circ} \mathrm{C}$ に加熱すると, 常圧でも(3)（の 反応が進行し，30〜50\% のスルファミン酸アンモニウムを含む 生成物が得られることがわかる。

表 1 イミド二硫酸アンモニウムの常殴アンモノリシス

\begin{tabular}{|c|c|c|c|c|c|c|}
\hline \multirow[b]{2}{*}{ 番号 } & \multicolumn{2}{|c|}{ 反庞条件 } & \multicolumn{3}{|c|}{ 生成物の租成 } & \multirow{2}{*}{$\begin{array}{c}Y^{\mathrm{b})} \\
(\mathrm{g} / 100 \mathrm{~g} \\
\text { 生成物 })\end{array}$} \\
\hline & $\begin{array}{l}\text { 温 } \\
(C)^{\text {度 }}\end{array}$ & $\begin{array}{l}\text { 時 間 } \\
\text { (min) }\end{array}$ & $\underset{(\%)}{\mathrm{NH}_{4} \cdot} \mathrm{NH}_{(\%)}$ & $\begin{array}{c}\mathrm{NH}_{4} \cdot \mathrm{NH}_{2} \\
\mathrm{SO}_{2} \mathrm{NH}\end{array}$ & $\begin{array}{c}\left.\left(\mathrm{NH}_{4}\right)_{2}\right)^{\circ} \\
(\%) \\
\left(\% \mathrm{O}_{4}\right.\end{array}$ & \\
\hline 1 & 250 & 60 & 30.5 & 65.6 & 3.9 & 56.1 \\
\hline 2 & $\left.280 \sim 250^{\mathrm{a}}\right)$ & 90 & 51.1 & 44.0 & 4.9 & 63.7 \\
\hline 3 & $275 \sim 285$ & 5 & 22.3 & 74.5 & 3.2 & 53.2 \\
\hline 4 & $255 \sim 285$ & 15 & 35.0 & 58.6 & 6.4 & 56.7 \\
\hline 5 & $275 \sim 290$ & 30 & 36.3 & 59.6 & 4.1 & 58.3 \\
\hline 6 & $245 \sim 275$ & 60 & 36.4 & 58.2 & 5.4 & 57.7 \\
\hline 7 & 280 & 60 & 40.9 & 54.2 & 4.9 & 59.7 \\
\hline
\end{tabular}

a) $280 \mathrm{C} て ゙ 30$ 分間反応させて完全に浴融させたのち, 徐々に 250 C まで盜度を 下げて反応させた。

b）反応生成物 $100 \mathrm{~g}$ を加水分解したときに生じスルファミン酸の $\mathrm{g}$ 数.

4) J. H. Thelin, P. A. van der Meulen, J. Am. Chem. Soc., 70, 1796 (1948). $280^{\circ} \mathrm{C}$ に损いて固体のイミド二硫酸アンモニウムにアンモニア ガスを通じる（番号 7 ）と，此較的すみやかに溶融夜となる。こ れを冷却して分析してみると，約 $40 \%$ のスルファミン酸アンモ ニウムが含まれ，また， $280^{\circ} \mathrm{C}$ で溶融させ，ついで徐々に冷却し て $250^{\circ} \mathrm{C}$ に下げると，スルファミン酸アンモニウムの含量が約 50\%になる（番号 2)。これはあとで述べるように，図 1 から説 明できる。

常殴のアンモニアガス中におけるイミド二硫酸アンモニウムの アンモノリシスは, $250^{\circ} \mathrm{C}$ 以下ではほとんど認められないが， $250^{\circ} \mathrm{C}$ 付近から次第に反応速度が増大し， $280^{\circ} \mathrm{C}$ ではかなりすみ やかになる。

ところで, 従来のスルファミン酸製造法では, アンモニアと三 酸化イオウとの反応でイミド二硫酸アンモニウムを主成分とする 反応生成物を作り，これを硫酸水溶液て処理して加水分解すると ともにスルファミン酸を析出させて分離した。

$\left(\mathrm{NH}_{4} \mathrm{SO}_{3}\right)_{2} \mathrm{NH}+\mathrm{H}_{2} \mathrm{O} \longrightarrow \mathrm{HSO}_{3} \mathrm{NH}_{2}+\left(\mathrm{NH}_{4}\right)_{2} \mathrm{SO}_{3}$

この際スルファミン酸アンモニウムも同様に硫酸水溶液で処理 すると,スルファミン酸が得られる。

$$
\begin{aligned}
& 2 \mathrm{NH}_{4} \mathrm{SO}_{3} \mathrm{NH}_{2}+\mathrm{H}_{2} \mathrm{SO}_{4} \\
& \longrightarrow 2 \mathrm{HSO}_{3} \mathrm{NH}_{2}+\left(\mathrm{NH}_{4}\right)_{2} \mathrm{SO}_{4}
\end{aligned}
$$

(3)，(4) 式を比べてみると,スルファミン酸アンモニウムの場 合は, 約同量の原料から 2 倍量のスルファミン酸が得られる。

そこで, $\mathrm{NH}_{3}-\mathrm{SO}_{3}$ 間の反応生成物をアンモニアガス中で 250 $\sim 280^{\circ} \mathrm{C}$ に加熱してイミド二硫酸アンモニウムをなるべくスルフ ァミン酸アンモニウムに変化させると, 表 1 の最後の欄に示した $Y$ の值のように, 原料 100 部から生じるスルファミン酸の量は約 60 部になる。これは $\mathrm{NH}_{3}-\mathrm{SO}_{3}$ 間反応生成物そのままの場合の 45〜48 部に比べてかなりの増加である。

\section{$3 \cdot 22 \mathrm{NH}_{4} \mathrm{SO}_{3} \mathrm{NH}_{2} \rightleftharpoons\left(\mathrm{NH}_{4} \mathrm{SO}_{3}\right)_{2} \mathbf{N H}+\mathrm{NH}_{3}$ の平衡}

各温度における平衡組成の測定結果を表 2 に示す。

これより常圧のアンモニアガス中における上記の平衡は, 温度 の低い方がスルファミン酸アンモニウム側に有利であることが明 らかである。また，アンモニアガス中でスルファミン酸アンモニ ウムを加熱すれば， $160^{\circ} \mathrm{C}: 96.0 \%, 200^{\circ} \mathrm{C}: 66.8 \%, 250^{\circ} \mathrm{C}: 54.0$ $\%, 310^{\circ} \mathrm{C}: 33.7 \%$ むスルファミン酸アンモニウムが分解せずに 残ることがわかる。

このことは, スルファミン酸アンモニウムの加熱分解によって イミド二硫酸アンモニウムを作る1)場合，乾燥空気を送って発生 したアンモニアガスをなるべく追い出し, 平衡をイミド二硫酸ア ンモニウム側に有利になるよらにする必要があることを示するの である。

この平衡は（5）式に示すように気-液（-固）間の平衡であり，

\begin{tabular}{|c|c|c|c|c|c|}
\hline \multirow[b]{2}{*}{ 番昂 } & \multicolumn{2}{|r|}{ 表 } & \multicolumn{2}{|c|}{2 平 衡 組 成 } & 成 \\
\hline & 㿿 $(c)^{\text {度 }}$ & $\begin{array}{l}\text { 時 閏 } \\
(\mathrm{min})\end{array}$ & $\overbrace{(\%)}^{\mathrm{NH}_{4} \mathrm{SO}_{3} \mathrm{NH}_{2}}$ & ${\overline{\left(\mathrm{NH}_{4} \mathrm{SO}_{(\%)}\right)_{2} \mathrm{NH}}}^{(\%)}$ & $\begin{array}{c}\left(\mathrm{NH}_{4}\right)_{2} \mathrm{SO}_{4} \\
(\%)\end{array}$ \\
\hline $\overrightarrow{1}$ & 160 & 360 & 96.0 & 2.5 & 1.5 \\
\hline 2 & 180 & 330 & 78.4 & 19.2 & 2.4 \\
\hline 3 & 200 & 230 & 66.8 & 28.4 & 4.8 \\
\hline 4 & 220 & 345 & 63.5 & 32.9 & 3.6 \\
\hline 5 & 250 & 180 & 54.0 & 44.4 & 1.6 \\
\hline 6 & 280 & 120 & 40.4 & 55.1 & 4.5 \\
\hline 7 & 310 & 120 & 33.7 & 62.7 & 3.6 \\
\hline
\end{tabular}
気相にはアンモニア, 液相にはスルファミン酸アンモニウムとイ 
ミド二硫酸アンモニウムが存在する。また, 後者は温度によって は固相としても存在する。

$$
\begin{array}{cc}
\text { (液) } & \text { (液) (固) (気) } \\
2 \mathrm{NH}_{4} \mathrm{SO}_{3} \mathrm{NH}_{2} \rightleftharpoons\left(\mathrm{NH}_{3} \mathrm{SO}_{3}\right)_{2} \mathrm{NH}+\mathrm{NH}_{3}
\end{array}
$$

イミド二硫酸アンモニウムとアンモニア側の反応は，アンモニ アが溶融液に溶けて反応することが考えられるが，常圧の場合は 溶融液中に溶けるアンモニアの量は，測定できないほど微量であ るので, 溶融液または固体の表面でイミド二硫酸アンモニウムと アンモニアガスが直接反応するものと思われる。

なお，平衡に到達する時間は温度の高いほど小であった。

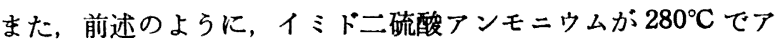
ンモニアとかなりすみやかに反応することは，表 1 番号 7 の結果

（加熱時間 60 分）が表 2 番号 6 の值に近いことからわかる。

また，スルファミン酸アンモニウムの熱分解拉よびイミド二硫 酸アンモニウムのアンモノリシスに拈いては, 少量の硫安が生成 するという問題がある。硫酸アンモニウムの生成量は, 測定した 温度範囲の $160 \sim 310^{\circ} \mathrm{C}$ では比較的短時間にある值となり，それ 以上加熱してもほとんど増加しないので，硫安の生成はこの平衡 と何らかの関係がありそうに思われる。しかし，この問題を取り 上げることは複雑になるので，今回はその生成量を示すにとどめ る。

\section{$3 \cdot 3 \quad \mathrm{NH}_{4} \mathrm{SO}_{3} \mathrm{NH}_{2}-\left(\mathrm{NH}_{4} \mathrm{SO}\right)_{3} \mathrm{NH}$ 间の燯点図}

測定結果を表 3，表 4 および図 1 亿示す。

図1に拈いて点Aはスルファミン酸アンモニウム, 点 $\mathrm{B}$ はイミ ド二硫酸アンモニウムの空気中における融点で，それぞれ 132.8 ${ }^{\circ} \mathrm{C}$ および $325^{\circ} \mathrm{C}$ 。また, 点 $\mathrm{C}$ は共融点で $124.2^{\circ} \mathrm{C}$, イミド二硫酸 アンモニウム $12.0 \%$ であった。

$\mathrm{NH}_{4} \mathrm{SO}_{3} \mathrm{NH}_{2}-\left(\mathrm{NH}_{4} \mathrm{SO}_{3}\right)_{2} \mathrm{NH}$ 間混合物の凝固点または融点の測 定は，温度が $160^{\circ} \mathrm{C}$ 以下では空気中でもスルファミン酸アンモニ

\begin{tabular}{|c|c|c|c|}
\hline $\begin{array}{c}\left(\mathrm{NH}_{4} \mathrm{SO}_{3}\right)_{2} \mathrm{NH} \\
(\%)\end{array}$ & 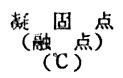 & $\begin{array}{l}\text { 基蠤㯰度 } \\
\text { (C) } \\
\text { (C) }\end{array}$ & 相 \\
\hline 0.0 & 132.8 & & $\mathrm{NH}_{4} \mathrm{SO}_{3} \mathrm{NH}_{2}$ \\
\hline 4.4 & 129.1 & (124.5) & $"$ \\
\hline 7.6 & 128.2 & (124.5) & " \\
\hline 11.0 & 125.8 & $(124.0)$ & " \\
\hline 12.0 & 124.2 & $124.2^{b)}$ & $\begin{array}{l}\mathrm{NH}_{4} \mathrm{SO}_{3} \mathrm{NH}_{2} \\
\left(\mathrm{NH}_{4} \mathrm{SO}_{3}\right)_{2} \mathrm{NH}\end{array}$ \\
\hline 14.8 & - & 124.6 & $\left(\mathrm{NH}_{4} \mathrm{SO}_{3}\right)_{2} \mathrm{NH}$ \\
\hline 15.0 & - & 124.0 & " \\
\hline 19.1 & - & 124.6 & " \\
\hline 25.4 & - & 124.6 & " \\
\hline 100.0 & $(325)^{a)}$ & & " \\
\hline
\end{tabular}

表 $3 \mathrm{NH}_{4} \mathrm{SO}_{3} \mathrm{NH}_{2}-\left(\mathrm{NH}_{4} \mathrm{SO}_{3}\right)_{2} \mathrm{NH}$ 間混合物の凝固点

a) とけると京時に分解し始める.

b) 共融点.

表 4 アンモニアガス中における $\mathrm{NH}_{4} \mathrm{SO}_{3} \mathrm{NH}_{2}-\left(\mathrm{NH}_{4} \mathrm{SO}_{3}\right)_{2} \mathrm{NH}$

\begin{tabular}{|c|c|c|c|}
\hline $\begin{array}{c}\left(\mathrm{NH}_{4} \mathrm{SO}_{3}\right)_{2} \mathrm{NH} \\
(\%)\end{array}$ & $\begin{array}{l}\text { 疑融点) } \\
\text { (C) }\end{array}$ & 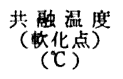 & 相 \\
\hline 0.0 & 132.8 & & $\mathrm{NH}_{4} \mathrm{SO}_{3} \mathrm{NH}_{2}$ \\
\hline 3.1 & 130.5 & (124.5) & " \\
\hline 7.3 & 129.0 & (124.5) & " \\
\hline 10.8 & 126.0 & $(124.5)$ & $"$ \\
\hline 13.3 & (146) & 124.2 & $\left(\mathrm{NH}_{4} \mathrm{SO}_{3}\right)_{2} \mathrm{NH}$ \\
\hline 18.0 & (173) & 122 & $"$ \\
\hline 26.7 & (200) & 123 & " \\
\hline 36.3 & (225) & 124 & " \\
\hline 52.9 & (273) & (123) & $"$ \\
\hline 64.7 & (282) & (124) & $"$ \\
\hline 79.1 & (305) & (125) & " \\
\hline
\end{tabular}
間混合物の凝固（融）点

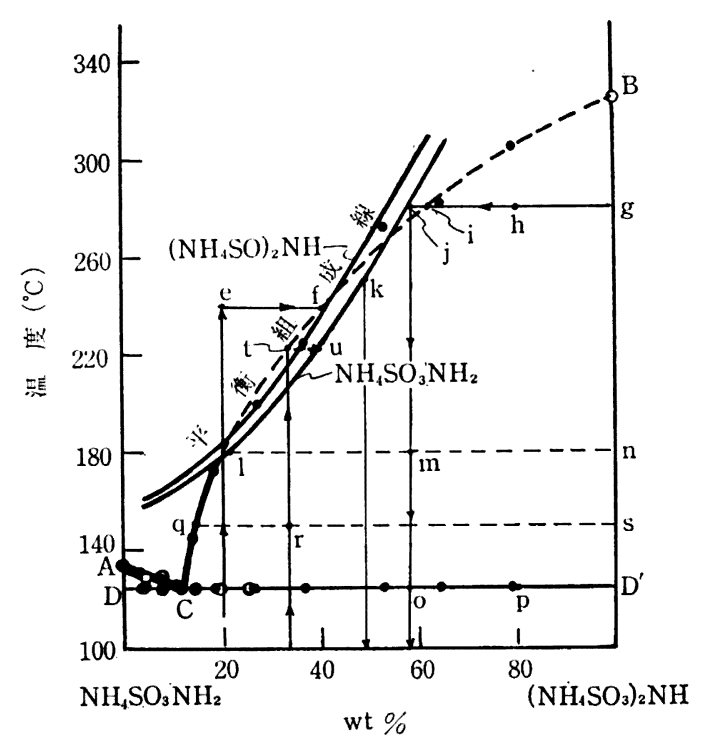

因 $1 \quad \mathrm{NH}_{4} \mathrm{SO}_{3} \mathrm{NH}_{2}$ と $\left(\mathrm{NH}_{4} \mathrm{SO}_{3}\right)_{2} \mathrm{NH}$ との混合物の融点 $O:$ 空気中で湖定，・：フンモニアガス中で测定

ウムが分解しないので，まず，空気中で $160^{\circ} \mathrm{C}$ 以下の場台を測定 し（表 3 ），ついで全般に亘ってアンモニアガス中で測定（表 4) した。

その結果, $160^{\circ} \mathrm{C}$ 以下では空気中でもアンモニアガス中でも凝 固点に变わりがなかった。测定法はスルファミン酸アンモニウム の融点から共融点に至る範囲では, 凝固点法で特に困難なく測定 できたが，共融点よりイミド二硫酸アンモニウムの含量の多い範 囲では，凝固点法で測定することが極めて困難であったので，融 点を測定した。ここに $180 \sim 270^{\circ} \mathrm{C}$ 間においては, 液相線（図 1 の $\mathrm{BC}$ 曲線) が後述の平衡組成線の左側にくるので, 測定中スル ファミン酸アンモニウムの一部が分解し，また， $270^{\circ} \mathrm{C}$ 以上では 液相線が平衡組成線の右側にくるため, イミド二硫酸アンモニウ ムとアンモニアとが反応して組成が平衡組成線に向って変化する ので， BC 曲線中破線で示した範囲は，正確な值を測定すること は困難であった。なお，共融温度は共融点 Cのイミド二硫酸アン モニウム $12.0 \%$ より約 $40 \%$ までは, 凝固点法で測定できたが, それ以上の範囲では測定が困難であったので，加熱の際の軟化温 度を測定した。

一方, $\mathrm{NH}_{4} \mathrm{SO}_{3} \mathrm{NH}_{2}-\left(\mathrm{NH}_{4} \mathrm{SO}_{3}\right)_{2} \mathrm{NH}$ 間の存在物質については, 図 2 に示す $\mathrm{X}$ 線回折図形においてスルファミン酸アンモニウムと イミド二硫酸アンモニウム以外の回折線が現われないことと, 困 1 に示す図形より，両者間には化合物も固溶体も生じないことが 明らかである。

図 1 において曲線 $\mathrm{BC}$ は，スルファミン酸アンモニウム溶融液 に対するイミド二硫酸アンモニウムの溶解度を示す。また， $\mathrm{ACB}$ より上の領域は溶融液、 $\mathrm{ACD}$ の領域では溶融液と固体のスルフ ァミン酸アンモニウム, $\mathrm{BCD}^{\prime}$ の領域では溶融液と固体のイミド 二硫酸アンモニウムがそれぞれ共存する領域で, $\mathrm{DCD}^{\prime}$ 線より下 の領域は固体のスルファミン酸アンモニウムとイミド二硫酸アン モニウムとが共存する領域である。

一方，図 1 に表 2 の平衡組成の数値を表わしてみると， BC 曲 線にやや入り込んた形の曲線になる。これは,スルファミン酸ア ンモニウムと, イミド二硫酸ケンモニウムの名温度の平衡状態に 


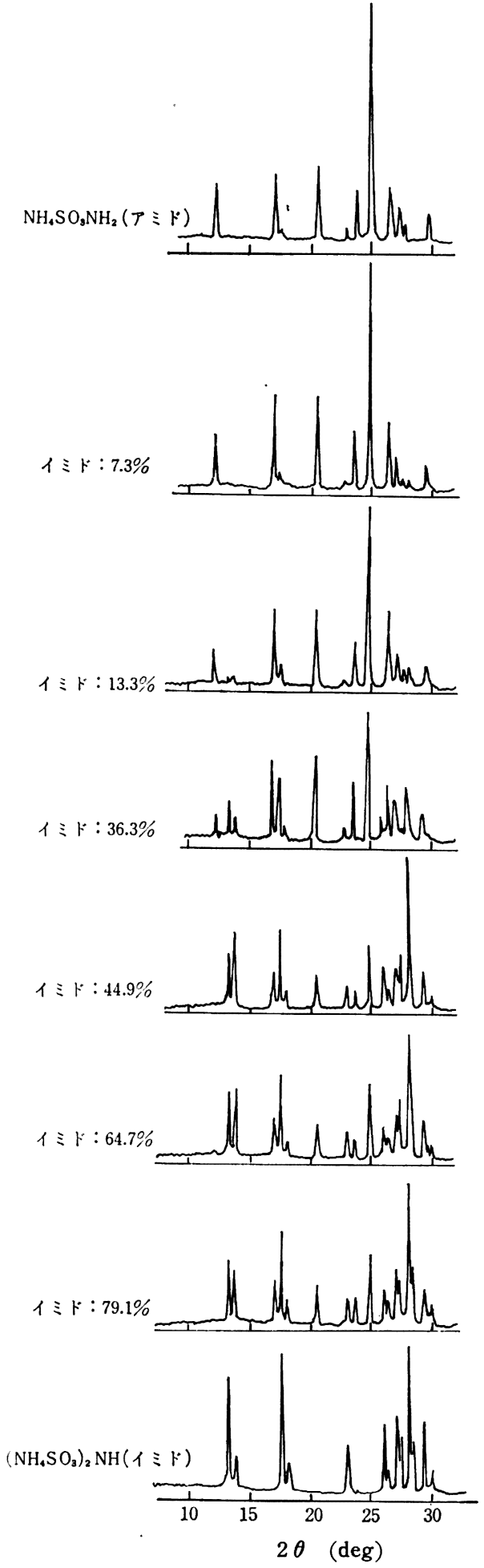

図 $2 \mathrm{X}$ 線回折図形 $\left(\mathrm{Cu} K_{\alpha}\right.$ 線)

おける含量曲線で，それらの間にはさまれた帯状の部分が硫酸ア ンモニウムを示すことになる。たとえば $230^{\circ} \mathrm{C}$ の場合の平衡組成 は, 図 1 から $\mathrm{NH}_{4} \mathrm{SO}_{3} \mathrm{NH}_{2} 58 \%,\left(\mathrm{NH}_{4}\right)_{2} \mathrm{SO}_{4} 4 \%,\left(\mathrm{NH}_{4} \mathrm{SO}_{3}\right)_{2} \mathrm{NH}$ 38\% と読みとることができる。

次にこれらを基として前述の（5）の平衡式における左辺および 右辺の反応を考えてみる。

$2 \mathrm{NH}_{4} \mathrm{SO}_{3} \mathrm{NH}_{2} \longrightarrow\left(\mathrm{NH}_{3} \mathrm{SO}_{3}\right)_{2} \mathrm{NH}+\mathrm{NH}_{3}$ の反応溶融液た
けが存在する領域において平衡組成線の左側の領域では, スルフ アミン酸アンモニウム単独あるいはこれとイミド二硫酸アンモニ ウムとのどのような混合液です不安定であり, 上式にしたがって アンモニアを放出しながら平衡組成線に至るまで組成が変化す る。例えばスルファミン酸アンモニウム $80 \%$, イミド二硫酸アン モニウム $20 \%$ の混合物を加熱して $230^{\circ} \mathrm{C}$ とすると, 点 $\mathrm{e}$ の溶融 液となるが，その組成は時間の経過とともに点 $\mathrm{f}$ （前記の $230^{\circ} \mathrm{C}$ の場合の平衡組成）に向って組成軸に平行に変化する。

$\left(\mathrm{NH}_{4} \mathrm{SO}_{3}\right)_{2} \mathrm{NH}+\mathrm{NH}_{3} \longrightarrow 2 \mathrm{NH}_{4} \mathrm{SO}_{3} \mathrm{NH}_{2}$ の反応 平衡組成 線より右側の領域において $250^{\circ} \mathrm{C}$ 以下ではかなり溶融液が共存す る場合でもすでに述べたようにほとんど反応が起こらない。しか し $250^{\circ} \mathrm{C}$ 以上ではイミド二硫酸アンモニウムまたはイミド二硫酸 アンモニウムとスルファミン酸アンモニウムとの混合物はアンモ ニアを吸収し，上記の反応にしたがって平衡組成線に至るまで組 成が変化する。とくに 289 290 C ではかなりすみやかに反応が 進む。

イミド二硫酸アンモニウムをアンモニア気流中で $280^{\circ} \mathrm{C} に$ 保つ と，そのアンモノリシスによってスルファミン酸アンモニウムが 生じるため固体のイミド二硫酸アンモニウムは次第に溶融し，そ の組成は $\mathrm{g}$ から点 $\mathrm{j}$ に向って変化する。途中の状態を検討してみ ると, 点 $\mathrm{h} て ゙ は$ 溶融液と固体のイミド二硫酸アンモニウムとの重 量比は $\mathrm{hg}$ : ih となる。そして液相線との交点 $\mathrm{i} に$ 近つくにした

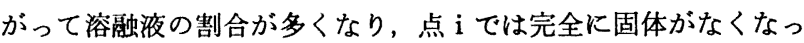
て均一な溶融液となる。さらに溶融液の組成が变化して平衡組成 線との交点 $\mathrm{j}$ に至る。四 1 より点 $\mathrm{j}$ の組成は $\mathrm{NH}_{4} \mathrm{SO}_{3} \mathrm{NH}_{2} 41 \%$, $\left(\mathrm{NH}_{4}\right)_{2} \mathrm{SO}_{4} 5 \%,\left(\mathrm{NH}_{4} \mathrm{SO}_{3}\right)_{2} \mathrm{NH} 54 \%$ で, その溶融液を急冷すれ ば，この組成の固体の生成物が得られる。これは表 1 番号 7 の実 験に相当するものであり, 結果も両者がほとんど一致している。

また，その溶融液を徐冷すると， $250^{\circ} \mathrm{C}$ までは応が進行する ので, 組成は平衡組成線に沿って点 $\mathrm{k}$ ま変化し，スルファミン 酸アンモニウムの生成量が增加する。しかし， $250^{\circ} \mathrm{C}$ 以下の温度 ではほとんど反応が進行しないので，これを冷却すれば $\mathrm{k}$ の組成 $\mathrm{NH}_{4} \mathrm{SO}_{3} \mathrm{NH}_{2} 51 \%, \quad\left(\mathrm{NH}_{4}\right)_{2} \mathrm{SO}_{4} 5 \% ，\left(\mathrm{NH}_{4} \mathrm{SO}_{3}\right)_{2} \mathrm{NH} 44 \%$ の固体 の生成物が得られる。これは表 1 番号 2 の実験に相当する。

これらより既報のアンモニア加圧下における反応起生温度 ${ }^{2)} に$ ついて考えてみると，30 atm のアンモニア加圧下でイミド二硫 酸アンモニウムを加熱した場合, $200^{\circ} \mathrm{C}$ 以下ではアンモノリシス の反応は生じないが，210〜 $220^{\circ} \mathrm{C}$ で急に反応が進さのは，従来 はイミド二硫酸アンモニウムがこの温度で溶融するため反応速度 が急に增大するものと考えていたが，これはまずこの温度になる と反応速度が急に大となるためであり，次に生じたスルファミン 酸アンモニウムの溶融液中にイミド二硫酸アンモニウムの一部が 溶け, アンモニア加圧下ではこの溶融液中にアンモニアが溶けこ むため，さらに反応が促進されるものと思われる。すなわち，温 度と溶融状態との相乗作用によって急速に反応が進むものと考え るのが妥当であろう。

困 1 の平衡組成線からわかるように（5) 式の平衡は温度の低い 方がスルファミン酸アンモニウム側に有利であるが, 常圧のアン モニアガス中における反応では, $250^{\circ} \mathrm{C}$ 以下では溶融液がかなり 存在する状態でもほとんど反応が進まないので，50\% 以上のス ルファミン酸アンモニウムを含む生成物を得ることは困難であ る。これはアンモニア加圧下の場合に比べて，溶融液中に溶ける 
アンモニアの量が微量であるため, 反応が気液の接触面において のみ起こるためであると思われる。

次に図 1 より高温に打ける溶融液を冷却していく場合の変化 を, 前述の常圧 $280^{\circ} \mathrm{C}$ の場合の生成物 $\mathrm{j}$ の組成の溶融液を例にと って検討してみよう。

急冷した場合は組成軸に垂直に変化するので，全組成には変化 がないが, $\mathrm{BCD}^{\prime}$ の領域内に入ると, 固体のイミド二硫酸アンモ ニウムが析出し始め, 温度が下がるにしたがってその量が次第に 多くなる。一方, 溶融夜の組成は $\mathrm{BC}$ 線に沿って共融点 $\mathrm{C}$ に向っ て変化する。たとえば $180^{\circ} \mathrm{C}$ まで冷却すれば，溶融夜の組成は 1 となり, 溶融液と固体イミド二硫酸アンモニウムとの重量比は $\mathrm{mn}: \mathrm{lm}$ となる*3。このようにして温度が下がるにしたがってま すます固体のイミド二硫酸アンモニウムの析出量が増加し, 共融 温度 $124^{\circ} \mathrm{C}$ に達すると, 液が全部固化するまで温度が一定とな る。ここに共融点 Cにおいては, 溶融液から析出する固体はイミ ド二硫酸アンモニウム $12 \%$ ，スルファミン酸アンモニウム $88 \%$ の混合物であって，次第に液から固体が析出していくと，析出物 の全組成は $\mathrm{D}^{\prime} \rightarrow 0$ に変化し, 最後に夜がなくなって点 $\mathrm{O} て ゙$ 固化 する。ここに途中点 $\mathrm{P}$ では析出固体の全組成は $\left(\mathrm{NH}_{4} \mathrm{SO}_{8}\right)_{2} \mathrm{NH}$ $80 \%, \mathrm{NH}_{4} \mathrm{SO}_{3} \mathrm{NH}_{2} 20 \%$ であり，Cの組成の溶融夜と析出固体と の比は OP : CO となる。

共融温度で全部固化した時の組成は前述のように $\mathrm{NH}_{4} \mathrm{SO}_{3} \mathrm{NH}_{2}$ $41 \%,\left(\mathrm{NH}_{4}\right)_{2} \mathrm{SO}_{4} 5 \%,\left(\mathrm{NH}_{4} \mathrm{SO}_{3}\right)_{2} \mathrm{NH} 54 \%$ であり, さらに温度 を下げてる相および組成の変化はない。

$\mathrm{j}$ の溶融液を徐冷し, $250^{\circ} \mathrm{C} て ゙ \mathrm{k}$ の組成の生成物を得た場合で も、これを冷却すれば上記に準じる変化をたどる。

\section{4 スルファミン酸アンモニウム加圧合成における イミトニニ硫酸アンモニウムの反応器への供給法}

はじめに述べたように, 加圧法によるスルファミン酸アンモニ ウムの製造の工業的実施に当って最も問題となることは, 固体の イミド二硫酸アンモニウムをどのようにして加圧反応器へ供給し ていくかという点である。

著者はこれについて，イミド二硫酸アンモニウムに適当量のス ルファミン酸アンモニウムをまぜ, 加熱溶融してイミド二硫酸ア ンモニウムが溶融液に眯濁または溶融状態として供給する方法を 考えたので，これを図1より検討してみる。

（1）懸濁法 スルファミン酸アンモニウムは $132.8^{\circ} \mathrm{C} て ゙$ 溶融 するが, $160^{\circ} \mathrm{C}$ までは空気中で分解しない。そこで共融温度の

*3 点 $\mathrm{j}$ の溶融液を冷却していくと, 実際には $220^{\circ} \mathrm{C}$ 付近で多 量の固体が析出して全体が固化するような感じになる。し かし,これは析出結晶中に溶解液が包含されるためであり， よくかきまぜれば多量の液が残っていることがわかる. $124.2^{\circ} \mathrm{C}$ から $160^{\circ} \mathrm{C}$ の間に打いて, 溶融塩中にイミド二硫酸アン モニウムを懸濁させて反応器へ供給することができる。

いま，原料のイミド二硫酸アンモニウムに 2 倍量のスルファミ ン酸アンモニウムを混ぜて加熱した場合を考えると，これは，前 述の高温に拈ける溶融塩の冷却過程と逆であり, たとえば, $150^{\circ} \mathrm{C}$ まで加熱すれば, 加えたスルファミン酸アンモニウムは, 全部溶 融夜となり,この溶融液にイミド二硫酸アンモニウムの一部が溶 けて残りの固体イミド二硫酸アンモニウムが懸濁した状態とな る。このとき, 溶融液の組成は qであり, 溶融液と固体イミド二 硫酸アンモニウムとの重量比は rs：qr となる。

工場操作において, このようなスラリーを連続的に反応器へポ ンブ輸送するには, 液の粘度やその他の問題があるので, スルフ アミン酸アンモニウムとイミド二硫酸アンモニウムとの混合比と 温度は実際の操作条件で試験を行なって決める必要がある。

（2）溶融法 上述の（1）の例において，アンモニアガス中で 加熱してさらに温度を上げてゆくと, 溶融液の量がますます増大 し, 液相線 $\mathrm{BC}$ との交点 $\mathrm{t}$ の温度 $223^{\circ} \mathrm{C}$ になると, 固点は完全に 溶けて均一な溶融液となる。そこで, これを加圧反応器へ供給す る。

しかし，点 $\mathrm{t}$ は平衡組成線の左側にくるので，スルフォミン酸 アンモニウムはその温度における平衡点 uに至るまで分解してい くことになる。実際的にもアンモニアの気泡が見られるが, 四 1 よりわかるように点 $\mathrm{t}$ は点 $\mathrm{u}$ に近い位置にあるので, 完全溶融に 近い状態で供給することができる。

（3）常圧アンモノリシスによる方法 前述のようにイミド二 硫酸アンモニウムをアンモニアガス中で $280^{\circ} \mathrm{C}$ に加熱すると， か なりすみやかにアンモニアと反応して約 $40 \%$ のスルファミン酸 アンモニウムを含む生成物が得られる。これをそのまま，または $250^{\circ} \mathrm{C}$ まで徐々に温度を下げて, さらにスルファミン酸アンモニ ウムの含量を增した後, 溶融液または溶融液に固体が懸濁した状 態として反応器へ供給する。

これは前述の3に拈いて述べたよらに，図1より容易に理解す ることができる。

以上三つの方法において (1) の方法はポンプ輸送が可能である が，(2）および（3）の方法では温度が高いので困難性があり，ポ ンブを用いない輸送法によらねばならない。

なお，以上は純イミド二硫酸アンモニウムと純スルファミン酸 アンモニウムを用いる場合について述べたが，実際には，前者は $\mathrm{NH}_{3}-\mathrm{SO}_{3}$ 間反応生成物をそのまま用い，後者は加圧反応生成物 の一部を循環使用する。

(昭和 39 年 4 月 1 日, 日本化学会第 17 年会講演)

終わりに本研究に協力された井川文雄君（当時明治大学工学部 学生）に感謝します。 